\title{
The development of students' internship model in Faculty of Engineering Universitas Negeri Yogyakarta
}

\author{
Wardan Suyanto, Dewi Eka Murniati, Pramudiyanto \\ Faculty of Engineering, Universitas Negeri Yogyakarta \\ Yogyakarta, Indonesia
}

\begin{abstract}
The study is a continuing research from the 1st year result which designed a model of students internship applied in Automotive Engineering study program in Faculty of Engineering Universitas Negeri Yogyakarta. The study aims to: 1) develop the model scope of student internship implementation to another study program including Electrical, Informatics, Mechanical, Automotive, Civil and Planning, Culinary, Fashion Design, and Beauty and Makeup, 2) develop students internship assessment to above study programs, 3) develop the debriefing curriculum to above study programs. This research was carried out on Electrical, Electronics, Mechanical, Automotive, Civil, Culinary, Fashion Design, and Beauty Makeup study programs. The research was conducted in the period of student's internship of the academic year 2016/2017 at various industry partners including Yogyakarta, Central Java, East Java, West Java, Bali, Jakarta, and East Kalimantan. The study population was all undergraduate/Diploma III students of the above study programs who carry out internship programs. Data were collected from inventory, observation sheets, in-depth interviews, and documentation. Content Validation analysis was done with expert judgment and FGD. Data were analyzed by qualitative descriptive analysis. The results of the research in this 2 nd year show that: (1) The model of student internship program designed for Automotive Engineering is no longer applicable for Electrical, Electronics, Machinery, Automotive, Civil Planning, Culinary, Fashion Design, Beauty Makeup study programs due to an unused component of the model. Therefore, the model scope has been developed to adjust for the current condition; (2) the students internship assessment should be improved that involves general competencies, technical competencies, portfolio, grading, and overall feedback from industry supervisor to student performance; (3) the curriculum for debriefing should be developed which involves program orientation, planning and placement, health and safety skills, hard skills, soft skills, and analytical skills.
\end{abstract}

Keywords—students internship model, assessment, debriefing curriculum

\section{INTRODUCTION}

The development of technological and vocational education learning must be continuously done by the institution so that the quality of the graduates is in accordance with the industrial competency demands. Technological advances and workplace dynamics are the challenges in achieving the prescribed competencies for vocational and vocational technology vocational/graduate teachers. Higher work competency of working field requires technological and vocational education institutions to be able to anticipate and deal with the changes that occur by utilizing the existing various capabilities. The quality of technological and vocational education outcomes of vocational/technological and vocational teachers both in terms of process and product is strongly influenced by the learning approach used in organizing technological and vocational education. The implementation of technology and vocational education cannot be without cooperation between educational institutions and the industry.

Work-based learning (WBL) is a learning approach that utilizes the workplace (industry) to structure experience gained in the workplace to contribute to the social, academic, and career development of learners and to be a supplement in learning activities. Workplace learning experiences are applied, refined, expanded in learning both on campus and at work. With WBL, the learners develop attitudes, knowledge, skill, insight, behaviour, habits, and associations from both places' experiences and allow learning to occur associated with reallife work activities (Lynch \& Harnish, 1998). Theories of experiential learning, context teaching and learning, and workbased learning become highly relevant in the administration of technology and vocational education. Technological and vocational education model development is required the various theories to improve the quality of learning outcomes that ultimately affect the quality of learning outcomes and the quality of graduates. Recent research results conclude that the use of Work-Based Learning Approach (WBL) in education has a positive influence on achievement, motivation, and continuing education (Bailey \& Merrit, 1997). Research and evaluation studies on the WBL show a correlation between outputs and graduate outcomes with learning structures that schools and industry provide in the workplace experience. When program objectives, workplace-based curriculums and experiences are designed and applied with adequate staff support and are properly evaluated, the program will have a positive impact (Lynch \& Harnish, 1998; Fallow \& Weller, 2000; Braham \& Pickering, 2007; Garnett, 2008).

The study is a continuing study from the first year result (Siswanto, 2015) which indicate that: (1) Integrated WBL model is suitable to be used in the implementation of internship / work-based learning on Automotive study program to improve the quality of learning outcomes; (2) outputs of the 
Integrated WBL model are: the knowledge / understanding of internship participants on WBL, professional attitudes, mental readiness of work, and student independence in the highergrade model significantly higher than the conventional class; (3) with multiple regression analysis, factors determinations affecting the quality of WBL learning outcomes are: management performance, student organizational culture, and WBL learning quality; and (4) program management and corporate management responses to the integrated WBL implementation model in the high category, both in the workbased learning concept, implementation in technical implementation, and their perception of WBL should be. Hence, this second-year study examines the applicability and the scope of model components. For the research objective sake, the study focuses on students' internship as one kind of WBL implementation programs (Chapman \& Hammond, 2013). Based on the WBL model founded in previous research, the model appendix, internship assessment, and internship curriculum are developed. The study aims to answer the problems in the implementation of internship including the limitations of strategy, model, and technical implementation in order to enhance the commitment of industrial / business involvement and to improve the quality and effectiveness of student learning outcomes that ultimately improve the quality of graduates.

The curriculum of all technological and vocational education programs begins by providing vocational foundations for learners. Furthermore, they will take a joint program between "work-based learning" and "school-based learning". Training programs that contain a larger proportion of industry work will provide more intensive work experience and higher levels of competence (Direktorat Dikmenjur, 2002: 59). An effective alternative for training on competency is an apprenticeship program or work-based learning as applicable in many countries. It may also be training activities conducted outside the workplace environment (off-the-job training) and on-the-job training activities (Smith, 2002). Thus it can be concluded, technological and vocational education with workbased teaching and learning approach (WBL) becomes a necessity. In reality, however, the problems facing technological and vocational education providers to collaborate with the industrial world (furthermore applying the concept of work-based learning in integrated technology and vocational education) are difficult to forge partnerships with industrycommitted education to help transition learners from the school world to the world of work and the scarcity of WBL program managers. Not many vocational education institutions already have MOUs for the transition. Besides the absence of legislation on the obligations of the industry to implement WBL together with technological and vocational education institutions, the institution organizes teaching and learning only based on school (school-based learning). This is, of course, less profitable for the implementation of technology and vocational education.

\section{RESEARCH OBJECTIVES}

In vocational education institutions, students nowadays are looser and have fewer rules to choose The implementation of students' internship on various study programs in vocational education in vocational institution nowadays are more freed and submitted to the students (FT UNY, 2006; FT UNS, 2007; FT UM, 2008). Variations of the various WBL models have not been seriously worked out as the WBL concept hopes as identified by the School-to-Work Administrative Team (STWA Team) and their working group (1997) that workbased learning is a connection of experiences planned and supervised learning with the expectations and realities of the working world. The WBL's experience gives learners the opportunity to develop and apply knowledge, skills, and employability attitudes that lead to better-informed career choices and engage in productive employment.

However, the implementation of students' internship as one WBL practices has some limitations in strategy, model, and technical accomplishment which affect the commitment of industry involvement, the quality and effectiveness of student learning outcomes, and ultimately the quality of graduates. This study investigates the model scope of student internship implementation founded in the first year study to other study programs including Electrical, Informatics, Mechanical, Automotive, Civil and Planning, Culinary, Fashion Design, and Beauty and Makeup, develops students internship assessment to above study programs, and develops the debriefing curriculum to above study programs.

\section{RESEARCH METHOD}

This research applied a research and development design by involving various methods through a qualitative approach. The research was conducted in all areas of Yogyakarta, Central Java, East Java, West Java, Bali, Jabodetabek, East Kalimantan, which were used as a place for the internship.

Firstly, data collection was gained by conducting focus group discussion between the internship coordinator of each department in FT UNY to formulate: (1) preliminary study of the scope of the model of internship on the study program of expertise: Electrical, Electronics, Machinery, Automotive, Civil Planning, Culinary, Clothing, Beauty Makeup that can improve the quality of learning outcomes. The research team mapped the implementation of the student internship and decided to take data in selected areas; (2) preliminary study on the code of conduct of student internship on the above study program; (3) preliminary study on internship assessment; (4) preliminary study on student internship curriculum. Secondly, data was obtained by sending some lecturers to selected internship places at once as an effort to retrieve research data. Lastly, collected the research data then do the coding and analysis qualitatively.

\section{RESEARCH FINDINGS}

The first year study has defined the components of internship model for automotive study program as follows in Fig 1. In the model, students get facilitation, monitoring, and evaluation from the Faculty of Engineering UNY as the academic institution who initiate the program. In addition, there is an online system that is built for the benefit of data collection and as a means of information of industrial activities called as INOPI (Innovation of Internship). INOPI provides 
data of students who are taking the course of the internship, the name of the supervising lecturer, the internship place, and the information about monitoring and evaluation. Students may also independently select their preferred counsellor until the supervising quota is met. The relationship between students and industrial premises is intertwined through company information, job information, assignments, and mentoring by industry supervisors. The industrial partners cooperate with program managers (academic institution) to communicate, formulate and develop the program curriculum.

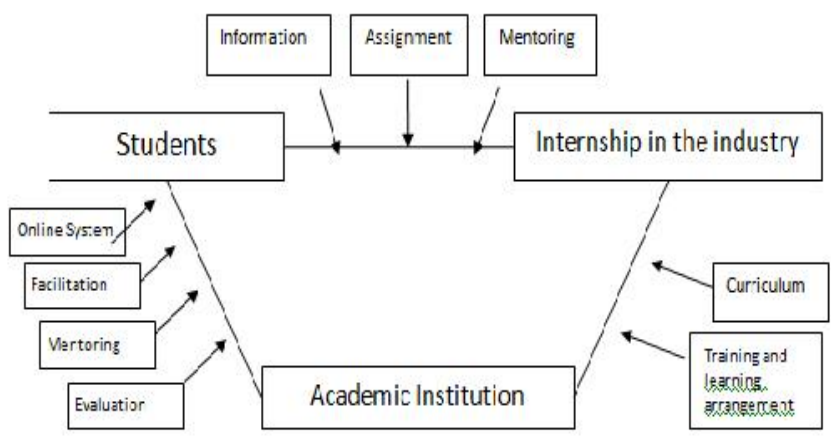

Fig. 1. Internship model founded in the 1st year result (Siswanto, 2015)

This research is a qualitative research by doing data analysis from an interview with students, supervisor/lecturer, internship program coordinator for each department, and industries. The results of observations and interviews conducted in this second-year study show some findings as follows:

1. The aspects of internship model scope should be reviewed as the following:

a. INOPI as the intranet online information system of an internship program in the FT UNY is not used as before (2014-2015). Input data was done manually by the education department in FT UNY but cannot be accessed freely. The need for data information can only be done by asking directly to the officer. In fact, INOPI provides complete information and thus facilitates the flow of information on the implementation of PI.

This is in accordance with what is said by lecturer FT UNY as one of PI's supervisor, Muh. Ali, MT:

"INOPI provides search feature of student's name and place of industry based on a study program, department, place/business area of the partner, and supervisor."

Thus, the monitoring and evaluation can be organized better and more effective. In addition, INOPI program can facilitate lecturers and students in conducting internship application letters, guidance, proposal uploads, and appraisals (http://pendidikanteknik-otomotif.ft.uny.ac.id/berita/workshop-

informasi -online-practices-industry-inopi.html).

However with no longer used this online system, therefore, the information status of student internship activities cannot be monitored properly. INOPI online system also has the limitation of not being integrated with SIAKAD (academic information system), which is difficult for users and administration officer.

b. Facilitation undertaken by the academic institution has been getting less serious attention. This can be shown from the student from Culinary study program.

"I really want to get some working experience in the kitchen, but I was only placed in the service area and it gives me less experience."

c. Monitoring and evaluation conducted by academic supervisors cannot be done well. This can be due to:

1) Lack of funds allocated in the internship monitoring and evaluation activities. Of the hundreds of FT UNY students who took internship program, only less than $10 \%$ who had received evaluation monitoring visits from lecturers.

2) Some industries did not meet the standards of internship program due to the industrial scale and working placement.

3) The absence of monitoring and evaluation instruments during lecturer visitation as a means of internship assessment and evaluation which made the monitoring program less useful and less informative.

d. The assignment is given by the industry to students often experience constraints due to several things. Firstly, the students were not employable in terms of soft skill and awareness to master the appropriate competence. As quoted by the chef of a hotel visited for monitoring evaluation:

"The student should be more active and an initiative to ask and propose an opinion on his assignment so that its implementation can be more clear and motivated."

While from a major contractor company in Indonesia, they argue:

"The student is actually smart, but they are discouraged to ask for clarification so that the assignment is wrong and almost fails."

Internship participants are also required to keep up to date and master common knowledge so he is able to be assigned to work outside the field of expertise. This is as revealed by BATAN (National Nuclear Power Institution) personnel: 
"The students protest for getting a job that is not in accordance with the field of expertise. While in fact, the student said he was from Electronics but have less concern in work safety, whereas safety is the common knowledge for every field."

Secondly, the industry parties have difficulty to conduct the internship process including mentoring, supervising, delegating or other forms. This is as stated by the chef of Pelataran Hotel, Magelang, Central Java.

"If the university has some demands regarding those (mentoring, supervising, delegating activities), then I will organize the student's activity. Since I have no guidance so I just simply put them in one section for 1 month under supervision, then let them do themselves afterwards. "

The same thing was also conveyed by Human Resource department of Aman Jiwo Hotel:

"We do not have the curriculum. The curriculum will depend on the needs of the company and not necessarily roll and judging by the ability of students. If the students look good in certain part, then he will be placed there."

e. The internship planning was prepared with the intention to realize the synergistic between the three sides of industry, academy, and students. However, to achieve harmony with one another, there are some notes to consider in order to achieve the expected internship implementation.

1) The internship administration such as correspondence of application, reporting guide, and assessment format.

2) The timing of the internship implementation often mismatch with industry needs when the program only takes place at a special semester every year but the industry requires the availability of internship students throughout the year. This was said by HRD Hotel Aman Jiwo:

"Actually we need internship students, not just this time. We hope we can get the internship students constantly taking turns."

3) The duration of implementation is limited to 2-3 months while the industry requires at least 3-6 months. This resulted in several consequences including 1) the student must request permission not to attend the class on campus due to undergoing internship program, 2) the student does not get the opportunity to have more experience and the job rolling because of the short duration of PI.

4) The internship planning related to the place, number and formation of student delivery. The program is expected to be prepared well in advance in order to arrange the formation of work in the industry. This is as Thiess Contractors Indonesia says:

"Initial planning on the number of students and formation requirements need to be done so the field of internship can be managed in advance."

5) Pre-training before internship program. The students were are expected to directly implement their knowledge and quickly learn. Nevertheless, some companies require training before fieldwork. This is as Thiess Contractors Indonesia says:

"The duration of 3 months is inadequate because there is mandatory training before joining the company. Unless the university provided mandatory training of the same standard then it makes it easier because students can go directly to the company. After students have mandatory training on campus, the company just checks their technical ability. "

2. The internship assessment must be improved and adjusted based on each study program attribute.

The form of assessment owned by FT UNY is available but has not been able to explore in detail and depth about the achievement of student competence. The instrument form is a questionnaire that contains some questions that are unable to represent indicators of the internship achievement. Therefore, the assessment in the form of interviews is expected to complement the existing assessment. The content of the assessment is aimed at soft-skills of students who felt less touched but in fact, soft skill is very much concerned by the industry. This was conveyed by several stakeholders:

"The mental must be strong because students are directly working in the field. A description of field conditions and situations should be prepared first. "

"The assessment is done by the user about safety, discipline, teamwork, initiative, presence, creativity."

"Must be critical, do not be silent. The initiative asks and asks for a job so that it gets a lot of experience."

"Students should be ready to do multitasking works."

3. The internship debriefing curriculum shall be welldeveloped for each study program.

The program implementation started with a briefing of all participants and some informants from industry. However, the debriefing is done together in a faculty level rather than in department level. In fact, each department has different characteristic each other which implies to a different curriculum. The curriculum in this briefing will be the basis of the students' knowledge before actually implementing the internship in the industry. 
The curriculum of the internship debriefing may include: 1) identification of the scope and definition of internship, 2) identification of the internship preparation, implementation and reporting rules; 3 ) identification of competencies required by the industry; 4) preparation of student competency checklist;

This study also found a fundamental need of the program implementation as an effort to get closer with industry, namely the need for sustainability partnership. The industry as a place of internship program should have proximity that always intertwined with FT UNY so that cooperation with industry can be conducted continuously. This can be realized by firstly cooperation agreement or MoU, secondly by the expansion of cooperation fields such as guest lecture, research collaboration, and industrial internships for lecturers as an effort to improve the quality of lecturers' competence as vocational teachers. Thirdly by giving attention to the industry about the seriousness of cooperation made between the two sides. This can be done by inviting pre-internship for the industry to unify the internship implementation objectives and identify industry needs to be tailored to the supply from the university to produce a mutual relationship internship program between industry and university.

\section{CONCLUSION}

The WBL model founded in the 1st year requires some adjustments and model implementation guidelines, particularly facilitation issues, INOPI, monitoring evaluation, and assignment of students internship.

In general, before the internship is organized, it is necessary to have good planning arrangement as an effort to debrief the students to field. This can be started from the provision of internship program has a clear and structured curriculum, and learning outcomes in accordance with internship objectives. The academy institution facilitation should have a wider scope of determining criteria for an internship, the industry requirement, and administrative facilitation. The monitoring and evaluation conducted by internship supervisors should have clear goals and objectives to deliver the mission of the program. The form of assessments has been applied so far need to be developed and improved. The assessment should include hard skill and soft skill assessment, as well as interpersonal skills through questionnaires and interviews. The debriefing curriculum should cover the identification of internship definition and scope, program preparation and planning, implementation and reporting rules, the recognition of competencies required by industry, student competency checklist, assessment, evaluation, and student portfolio.

\section{REFERENCES}

[1] Bailey, T. \& Meritt, D. (1997). Youth apprenticeship: lesson from the U.S. experience. CenterFocus, 1. Diakses 8 Agustus 2008, National Center for Research in Vocational Education dari: http://ncrve.berkeley.edu/CenterFocus/cf1.html.

[2] Braham, J. \& Pickering, J. (2007). Widening participation and improving economic competitiveness; the dual role of work-based learning within foundation degrees. Proceedings of The Work-based Learning Futures Conference, UK, Buxton, April 2007, 45-52.

[3] Chapman, M. F. R. and Hammond, L. D. 2013. Preparing 21st Century Citizens: The Role of Work-Based Learning in Linked Learning. Retrieved from https://edpolicy.stanford.edu/sites/default/files/publications/preparing21st-century-citizens-role-work-based-learning-linked-learning.pdf

[4] Direktorat Dikmenjur. (2002). Pokok-pokok pikiran pengembangan pendidikan kejuruan menjelang 2020. Dalam Dedi Supriadi (Ed.), Sejarah pendidikan teknik dan kejuruan di Indonesia (pp. 585-602). Jakarta : Direktorat Jendral Pendidikan Dasar dan Menengah.

[5] Fallow, S., \& Weller, G. (2000). The transition from student to employee: a work-based program for "graduate apprentices" in small to medium enterprises. Journal of Vocational education Training, 52(4), 665-685.

[6] FT UNY. (2006). Buku Pedoman Praktik Industri.

[7] Garnett, J. (2008). Recognising and enhancing the quality of university work-based learning programmes. Proceedings of the work-based learning futures II conference, UK, Middlesex, May 2008, 32-38.

[8] Lynch, R.L. \& Harnish, D. (1998). Preparing pre-service teacher education students to used work-based strategies to improve instruction. In Contextual teaching and learning: Preparing teachers to enhance student success in the workplace and beyond (pp. 127-158). Columbus: OH: ERIC Dearinghouse on Adult, Career, and Vocational Education.

[9] Siswanto. B. T. (2015). Model penyelenggaraan Praktik Industri/workbased learning pada PROGRAM STUDI KEAHLIAN: Elektro, Elektronika, Mesin, Otomotif, SipilPerencanaan, Boga, Busana, Rias Kecantikan. Penelitian UPT, tidak diterbitkan, Ditlitabmas, Dikti.

[10] Smith, E. (2002). Theory and practice: the contribution of off-the-job training to the development of apprenticeship and trainee. Journal of Vocational and Education Training, 4(3), 431-456. 